OnLine Journal of Earth Sciences 5 (1): 1-5, 2011

ISSN: 1991-7708

(C) Medwell Journals, 2011

\title{
Study on the Reproduction of the Species Aglaiella stagnalis (Ostracoda) From the Bottom Sediments of Lake Qarun (Egypt)
}

\author{
${ }^{1}$ Salah Bahr, ${ }^{2}$ Zakia Riad and ${ }^{3}$ Mohamed Amin Bassiouni \\ ${ }^{1}$ Department of Environment and Earth Sciences, Islamic University, Gaza, Palestine \\ ${ }^{2}$ Department of Zoology, Faculty of Women, Ain Shams University, Cairo, Egypt \\ ${ }^{3}$ Department of Geology, Ain Shams University, Cairo, Egypt
}

\begin{abstract}
Different development stages of the genus Aglaiella stagnalis (ostracodes) were observed in field and laboratory. The study aimed to check up the cell division and the identity of chromosomes for the species Aglaiella stagnalis. Samples were collected in monthly bases on the period from October 1978-1980 from Auberg location. A large number of metaphases could be speculated, each metaphase includes a number of chromatin masses which were presumed to be the chromosomes in metaphase. Their number per nucleus varied between 8,24 and 12 was the most common number. Each presumed chromosome occurred as a clump of chromatin with no differentiation to arms or centromeric part and they do not equal in size where in each metaphase three of these masses are larger than the rest of set. In dissected animals, some developing youngs could be spotted in the gonads all at the same stage of development. These populations of gonadal cells were either in metaphase or showed one or another uniform stage of embryonic development. The picture on the whole gives an impression of a sort amitotic division followed by parthenogenetic development of the youngs in vivo.
\end{abstract}

$\underline{\text { Key words: Metaphase, chromosome, gonadel cells, embryonic development, populations, laboratory, Egypt }}$

\section{INTRODUCTION}

Lake Qarun, situated in Egypt is presently a salt water lake situated about $90 \mathrm{~km}$ South West of Cairo in the Fayoum depression, not far from the Nile valley. Soliman (1989) describes it as confined to latitudes $29^{\circ} 24^{\prime} 39^{\prime \prime} \mathrm{N}$ and $29^{\circ} 32^{\prime} 38^{\prime \prime} \mathrm{N}$ and longitude $30^{\circ} 27^{\prime} \mathrm{E}$ to $30^{\circ} 44^{\prime} 38^{\prime \prime} \mathrm{E}$. Figure 1 shows the location of the Lake Qarun. The maximum depth of lake is $8.5 \mathrm{~m}$ to the West of EI-Qarn Island and the Eastern part is shallower with depth of about $3 \mathrm{~m}$ (Mohunta, 2008). It has a roughly elongate shape with the long axis lying East-West (Mohamed and Gad, 2008). It is surrounded by cultivated lands in the Southern and South Eastern parts and bordered by the desert in the Northern part.

Historically, the total area and sea level of the lake was dramatically decreased (Fig. 2). The Lake Qarun today is $45 \mathrm{~m}$ below sea level and has a surface area of $214 \mathrm{~km}^{2}$. It has a maximum depth of just $>8 \mathrm{~m}$ and a volume of 800 million $\mathrm{m}^{3}$. It is $42 \mathrm{~km}$ long and $9 \mathrm{~km}$ wide at its broadest point

About 370 million $\mathrm{m}^{3}$ of drainage water reach the lake annually and as the lake level now stays fairly constant and there are no known outlets, this annual drainage water quantity is also taken as the annual rate of

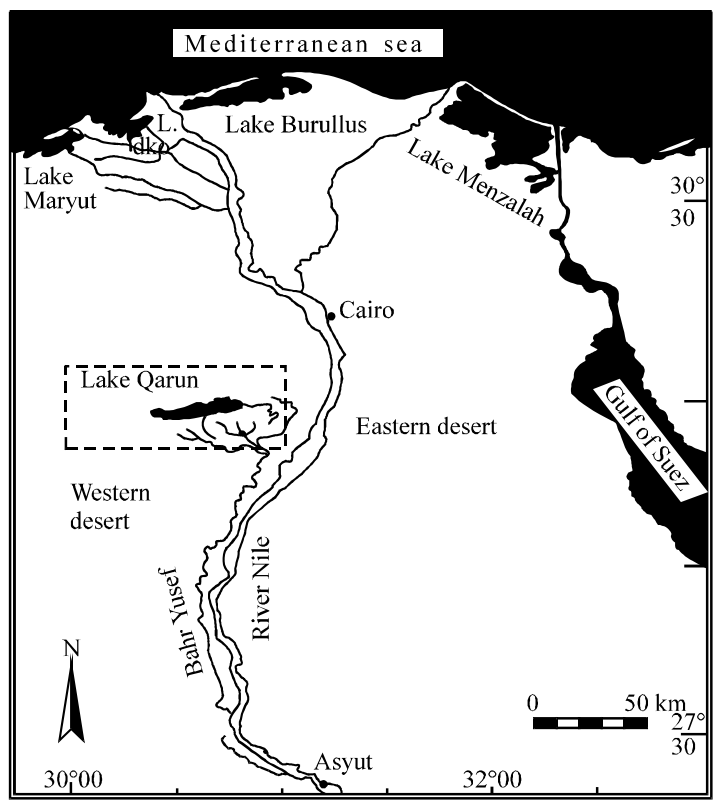

Fig. 1: Location map of Lake Qarun

evaporation. If follows that if the water supply to the lake were cut off, it would dry up in 2 years. The high rate of evaporation has led to a concentration of salts, the lake is

Corresponding Author: Salah Bahr, Department of Environment and Earth Sciences, Islamic University, Gaza, Palestine 
OnLine J. Earth Sci., 5 (1): 1-5, 2011

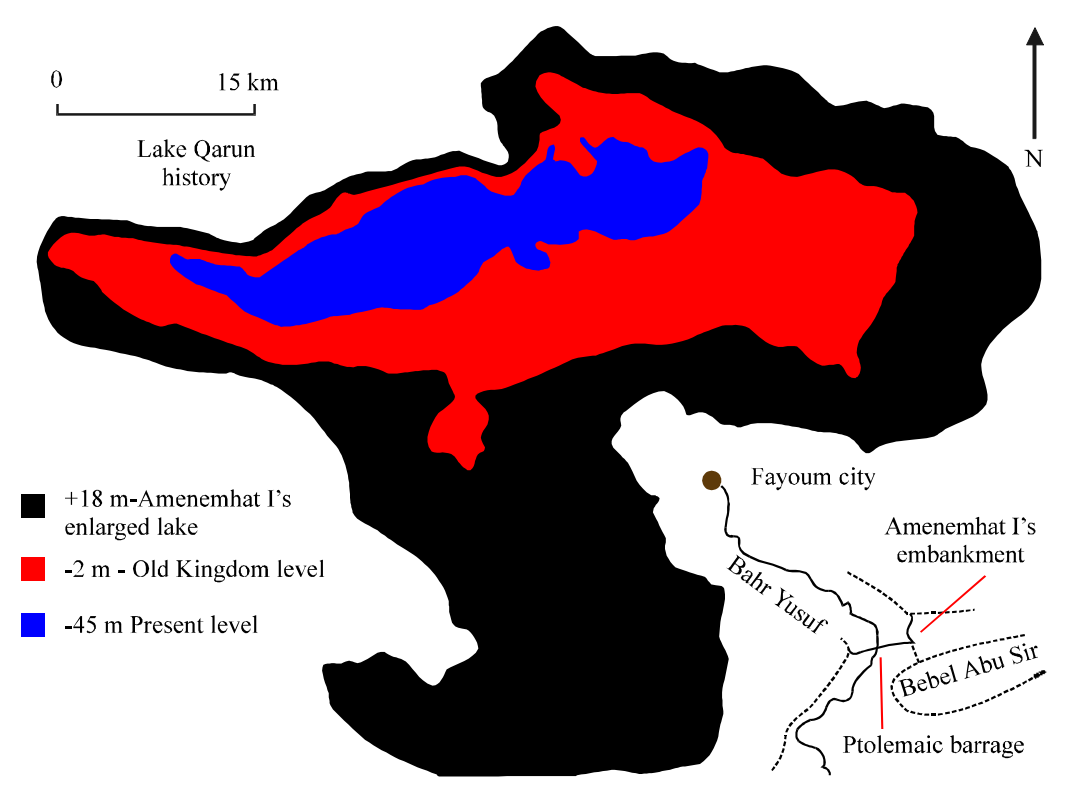

Fig. 2: Historical map of Lake Qarun

now as saline as the sea water with a ratio of around 34.5 parts per thousand, said to be growing at the rate of 0.4 parts year $^{-1}$. For comparison, sea water ranges between 34 and 37 per thousand while Jordan's Dead sea has between 300 and 330 per thousand. The water is less salty in the East and the South of the lake where the two main canals bring in fresh water.

When a fresh water lake starts turning gradually saline most of the fresh water flora and fauna die some adapt and survive for some time until the salinity increases beyond their ability to adapt and these also disappear. The surrounding flora also starts disappearing until the whole area is dead. Thus, an ecological disaster happens and entire area becomes inhabitable for nature as well as men. The salinity of Lake Qarun rose frome $3.5 \mathrm{~g} \mathrm{~L}^{-1}$ in 1890 's to $26 \mathrm{~g} \mathrm{~L}^{-1}$ in 1950 and was predicted that it would reach almost $50 \mathrm{~g} \mathrm{~L}^{-1}$ by 2005,2010 (Mohunta, 2008).

The lake receives its budget of water as drainage from the neighboring cultivated lands through a system of twelve drains, among which-El-Bats and EI-Wadi drains are the main channels joining the lake at the East and Mid-South sides, respectively while the other 10 drains are very small and add comparatively little water to the lake. The cultivated lands of Fayum receive its water supply indirectly from the Nile through Bahr Yusef which are the later branches from Ibrahimiya canal at a point near Assiut in upper Egypt (Fig. 1). Bahr Yusef runs North wards parallel to the Nile for about $240 \mathrm{~km}$ and then bends to the West to reach the Fayum by means of two main branches Lake Qarun extends for about $40 \mathrm{~km}$ from East to West and its breadth is about $5.7 \mathrm{~km}$ to South. The lake attains its maximum breadth $(9.25 \mathrm{~km})$ in the Western part, West of El-Qarn Island. The water covers an area of about $235 \mathrm{~km}^{2}$ (about 53,000 feddans) and usually affected by the influx of the drained water which either increases or decreases the lake every year. However, the volume of the water in the lake is varying according to the changes in its water level which fluctuates every year owing to the amount of flooded water through the drainages, amount of rainfall and the rate of evaporation.

The mean depth of the lake defined as volume/area is about $4 \mathrm{~m}$. The Western part of the lake is relatively deeper than the Eastern part (Ball, 1939) while the shallowest region lies at the South Eastern part of the lake where, it is subjected to the influence of land drainage which carries a considerable amount of mud that settles down near the mouth of the drain.

The shores of the lake are generally covered by shells of Mollusca and are characterized by the spreading of small marches crowded by weeds. El-Wakeel (1964) stated that the sediments of Lake Qarun are poor in the organic content due to the presence of sulpher reducing bacteria which prevents the accumulation of significant organic matter in the sediments. The decomposition of the organic matter is accelerated by the considerable high temperature prevailing in locality during most of the year (El-Wakeel, 1964).

Objective of the study: The new trend now-a-days is to study the living forms as a part of the plan of studies of the paleontological section for a better understanding of the fossil forms. The study was planned to check up the cell division and the identity of chromosomes for the 
species Cyprideis c sohni which was the dominant species along the year in the area of study in order to compare between the smooth and noded types but unfortunately no results could be obtained on the smooth species and the noded species did not appears under any conditions of changes in salinity. However, the Aglaiella stagnalis species appeared suddenly in the aquaria; its gonads were in the proper time and were suitable for identification of the chromosomal picture.

\section{MATERIALS AND METHODS}

One locality of the Lake Qarun was selected for the present study; it is an area near the Auberg (Fig. 3). Auberg sampling area is an area which was chosen for over year aquarium studies. It is shallow marches crowded with plants (Fig. 4). Monthly visits to this locality were periodically performed through the period from October 1978-1980. During these visits, samples of water were collected. Care was taken to go down as deep as possible in order to catch a fairly good collection of the bottom sediments fauna. The samples were then transferred to laboratory in Cairo where, they were kept in aquaria of $25 \times 20 \times 25 \mathrm{~cm}$ for length, width and height, respectively. The depth of water was kept about $2 / 3$ the depth of the aquarium by addition of water from the same locality, then the water was artificially aerated. For sake of biological studies, the animals needed to be narcotized before handling. Several narcotics were tested.

They include alcohol, tobacco smoke, carbon dioxide and gentle heating to $30-35^{\circ} \mathrm{C}$. Alcohol proved to be the best narcotic. Addition of few drops to a watch glass containing a suspension of ostracodes brings about complete muscular relaxation within $15 \mathrm{~min}$. Then the valves become widely opened, allowing for proper handling and dissection. Chromosome preparations were obtained from the gonads. Attempts were also made to select a suitable fixative. The Bouin, calcium formal and carnoy were tried. The modified Carnoy (1:3 glacial acetic acid:alcohol) proved to be the best fixative. It caused fixation of the soft tissues and decalcification of the shell at the same time. Dissection was carried out under a binocular microscope using sharply pointed needles. For staining, few drops of aceto-orceln were put on the dissected soft parts for 10-15 min after which excess of stain was removed by a filter study. The stained soft parts were covered by a cover glass and squashed by pressing using the thumb. The excess of stain was removed by

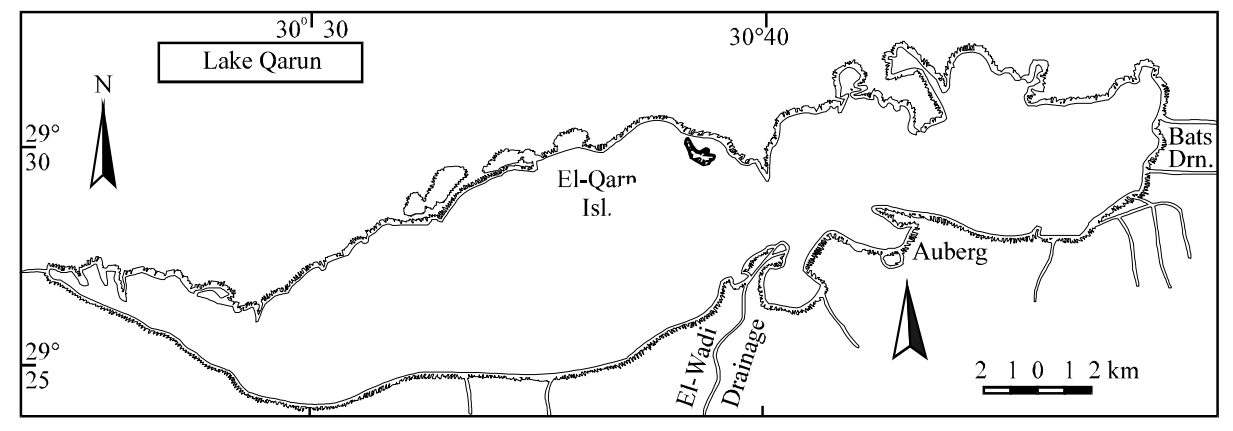

Fig. 3: Map of sampling station in Lake Qarun (Auberg)

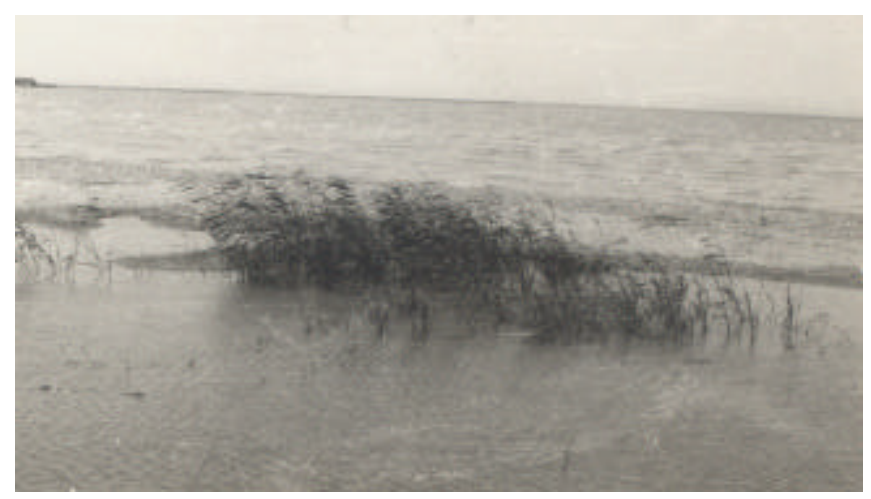

Fig. 4: Photo of Auberg sampling location 
placing the slide within a folded filter study and the cover was finally sealed by nail polish. The slides were examined using oil immersion lens with $90 \times$ magnification power. Necessary microphotographs were obtained using the same magnification. It is necessary to state that better results were obtained when yeast was added to the specimens isolated in small jars for 1 or 2 days before dissection.

\section{RESULTS AND DISCUSSION}

The two ostracode species Cyprideis (cyrpideis) shoni and Agilaiella stagnalis were found together with some gastropodes and worms, beside few aquatic plants, e.g., Chara in aquaria containing water from the selected Auberg near locality. Association sample obtained from an aquarium at the time of flourishing of Aglaiella stagnalis shown in Fig. 5 and 6a-f. The sample contains:

- Algaiella stagnalis (Moore, 1961)

- A worm

- A chara plant with a lateral oogonia

- Enlarged oogonia of chara plant
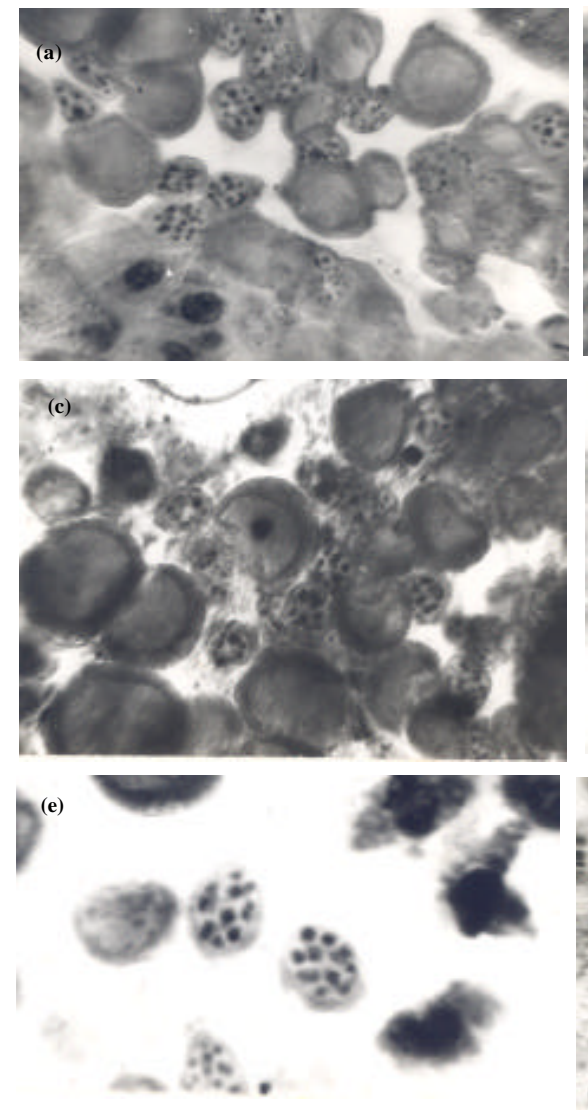

Fig. 6: Squashed gonads from several animals showing clumps of metaphase chromosomes
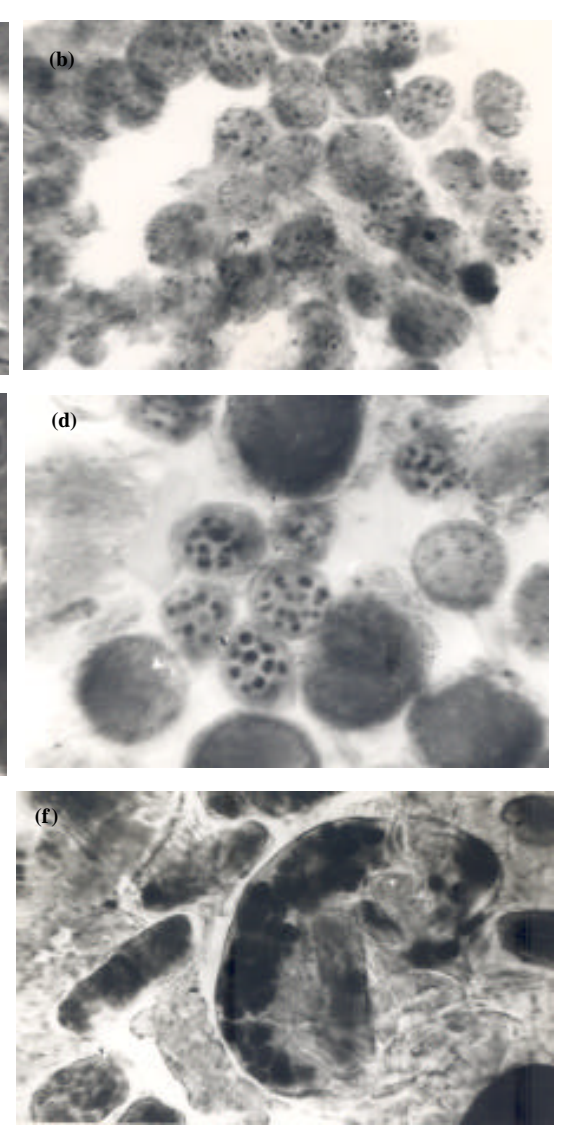

An approach which was attempted during the study of the biology of ostracodes is a genetic study on the genus Aglaiella stagnalis. The genus proved to be more suitable for such research, the gonads were actively dividing most of the time and this allowed for the present chromosomal studies. Different developmental stages of Aglaiella stagnalis were observed in field and laboratory

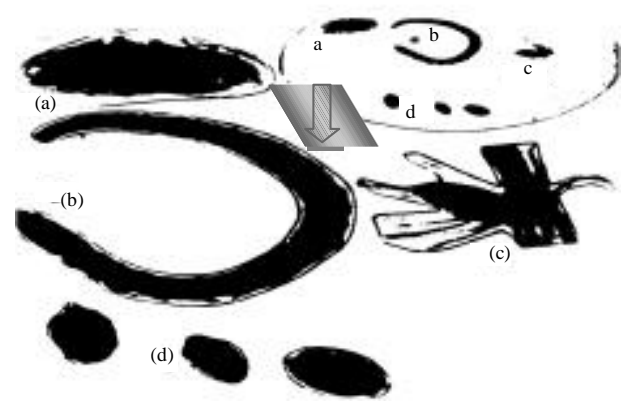

Fig. 5: Photo presents part of ostracode species community $\times 25$ where: a) Algaiella stagnalis; b) Worm; c) Chara plant with a lateral oogonia and d) enlarged oogonia of Chara plant 


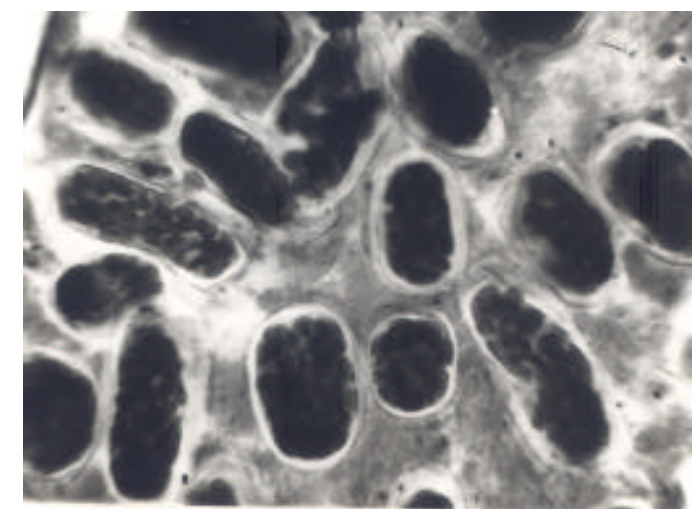

Fig. 7: An enlarged photograph (x2000) of the developing young's in ground of Algaiella stagnallis

material in very high numbers by the end of November with regards to field collected material the highest population was in brackish water.

On the cytogenetic level and by the end of November to the end of January 1979, the gonods showed active mitotic activity and hence this material was suitable for such genetic study. By squashing of the gonads of adult animals, a large number of metaphases could be speculated. The photos shown in Fig. 6 represent squashed gonads from several animals showing clumps of metaphase chromosomes (x2000).

Each metaphase includes a number of chromatin masses. These were presumed to be the chromosomes in metaphase. The number of masses per nucleus varied between 8 and 24 chromosomes. Through the counting of 90 metaphases, 12 chromosomes were found to be the most common number. Each presumed chromosome occurred as a clump of chromatin with no differentiation to arms or a centromeric part. However, they do not seem to be equal in size. In each metaphase, three of these masses were evidently larger in size than the rest of the set. It is necessary to state that no sex differentiation could be speculated. This observation holds for the morphological appearance of the Aqlaiella stagnalis as well as the chromosomal level. Moreover in some of the dissected animals, some developing youngs could be spotted in the gonads (Fig. 6). A group of developing embryos could be spotted in the gonads all at about the same stage of development. This observation was frequently spotted. In some cases each developing embryo appeared as an oval body formed of many identical cells. In some others, the embryo had an elongated appearance thus giving an impression of organic differentiation as showed in Fig. 7. Note that they are nearly at the same stage of development.

\section{CONCLUSION}

In this study it is necessary to state that cells of one gonad did not show a photograph of the more than one picture. The populations of the gonadal cells were all either in metaphase or showed one or another uniform stage of embryonic development. The picture on the whole gives an impression of a sort amitotic division followed by parthenogenetic development of the youngs in vivo.

\section{REFERENCES}

Ball, J., 1939. Contribution to the Geography of Egypt. Government Press, Cairo.

El-Wakeel, S.K.M., 1964. A study of the bottom deposits of lake Qarun, Egypt-Part 2. Chemical investigations. Bull. Fac. Sci. Alex. Univ., 5: 57-80.

Mohamed, F.A.S. and N.S. Gad, 2008. Enviromental pollution-Induced biochemical changes in the tissues of Tilapia zillii, Soles vulgaris and Mugil capito from lake Qarun, Egypt. Global Veterinaria, 2: $327-336$.

Mohunta, D.M., 2008. Preventing an ecological disaster-The saving of Lake Qarun. http://www.ecoweb.com/edi/index.htm.

Moore, C.R., 1961. Treatise on Invertebrate Oaleontology, Part Q-Arthropoda 3-Crustacea-Ostracoda. University of Kansas Press, United States.

Soliman, G.F., 1989. The hydrology of Lake Qaroun, Fayonm province, Egypt, Part. I: Physical environmental conditions. Bull. Nat. Inst. Oceanogr. Fish. ARE, 15: 75-92. 